\title{
The Fragility of Climate, Human Responsibility and Finding the Impetus to Act Decisively-Investigating the Potential of the Ethics of Care
}

\author{
Karen Morrow \\ Professor of Environmental Law \\ University of Swansea/Prifysgol Abertawe, United Kingdom
}

\section{INTRODUCTION: RIGHTS, RESPONSIBILITIES, AND CLIMATE CHANGE}

Human rights-based approaches are, after a lengthy gestation, ${ }^{1}$ emerging as a leading potential response to a partly socially ${ }^{2}$ and increasingly ecologically generated consciousness of humanity's embeddeness in and consequent vulnerability to changes in the environment in general, ${ }^{3}$ and to climate change in particular. ${ }^{4}$ That human rights have a potentially significant role to play in this regard is now perhaps a given, ${ }^{5}$ if controversial on both particulars and some practicalities. ${ }^{6}$ The potential of human rights-based claims to address at least some issues of inter-societal equity (albeit for the most part on an individualistic rather

\footnotetext{
${ }^{1}$ See. for example, the enlightening contextual discussion of the problematic nature of the human rights/development/environment interface in Philip Alston, 'Ships Passing in the Night: The Current State of the Human Rights and Development Debate seen through the Lens of the Millennium Development Goals' (2005) 27(3) Human Rights Quarterly 755.

${ }^{2}$ See for example, Neil Leary, Cecilia Conde, Jyoti Kulkarni, Anthony Nyong, Juan Pulhin (eds), Climate Change and Vulnerability (Earthscan, 2008), which raises gender, race and class as among socially salient considerations in the context of climate change.

${ }^{3}$ See for example, Will Steffen et al., 'Planetary Boundaries: Guiding human development on a changing planet' (15 January 2015) Science Express 1, available at <http://www-ramanathan.ucsd.edu/files/pr210.pdf $>$ [accessed on November 28th, 2017].

${ }^{4}$ There is a wealth of scholarship in this area, see for example, John Knox 'Linking Human Right and Climate Change and the United Nations' (2009) 33 Harvard Environmental Law Review 477; and Stephen Humphries (ed), Human Rights and Climate Change (Cambridge University Press, 2010).

${ }^{5}$ See for example the UNHRC-commissioned Report of the Special Rapporteur on the issue of human rights obligations relating to the enjoyment of a safe, clean, healthy and sustainable environment, A/HRC/31/52, 01 February 2016 available at

$<$ http://www.ohchr.org/EN/Issues/Environment/SREnvironment/Pages/ClimateChange.aspx $>$ [accessed on December 11th, 2017]; and UNEP/Sabin Center for Climate Change Law, Michael Burger, Jessica Wentz et al.: Climate Change and Human Rights (UNON Publishing Services Section, 2015), available at $<$ http://columbiaclimatelaw.com/files/2016/06/Burger-and-Wentz-2015-12-Climate-Change-and-HumanRights.pdf $>$ [accessed on December 11th, 2017].

${ }^{6}$ See, for example, Sumudu Atapattu, Human Rights Approaches to Climate Change: Challenges and Opportunities (Routledge, 2016).
} 
than a collective level $^{7}$ ) for example, is strongly arguable. However, even where solely interhuman claims are in play, the capacity of human rights to address other key issues, such as intergenerational equity concerns, is, given the inherent constraints of prevalent models of rights-bearing, considerably less convincing. ${ }^{8}$ In any case, the instrumental treatment that human rights claims accord to the environment means that they are ill-equipped (and perhaps even unable) to respond fully to ecological realities.

This chapter argues that human rights-based approaches cannot, in isolation, bear the weight of the considerable societal challenges that climate change poses and will pose at all levels from the local to the planetary. The central contention here is that, ongoing climate change being acknowledged as substantially (though not solely) anthropogenic ${ }^{9}$ in nature and with the whole of humanity being implicated (albeit to highly varying degrees), ${ }^{10}$ any effective approach to addressing it also requires the adoption of a workable conception of human responsibility.

The notion of responsibility has long been present in international environmental law, for example, in the preamble to the Stockholm Declaration, where it appeared in a particularly expansive form, embracing not only states, the traditional subjects of international law, but also extending to citizens, communities and enterprises. ${ }^{11}$ Nevertheless, it remains the case that, despite the ostensible change in tack prompted by the advent of sustainable development

\footnotetext{
${ }^{7}$ Latterly there has been some development in addressing collective rights claims in environmental contexts, predominantly with reference to indigenous peoples, see, for example, Evadne Grant, 'International Human Rights Courts and environmental human rights: re-imagining adjudicative paradigms' (2015) 6(1) Journal of Human Rights and the Environment 156.

${ }^{8}$ See, for example, Burns H, Weston, Tracy Bach, Climate Legacy Initiative, Climate change, human rights and intergenerational justice (Vermont Law School, 2009); and Lynda Collins, 'Environmental Rights for the Future? Intergenerational Equity in the EU' (2007) 16(3) Review of European, Comparative \& International Environmental Law 321.

${ }^{9}$ Notably the ongoing, painstaking work of the Intergovernmental Panel on Climate Change (IPCC) and in particular, IPCC, Climate Change 2014: Synthesis Report Summary for Policy Makers (2014), available at $<$ https://www.ipcc.ch/pdf/assessment-report/ar5/syr/AR5_SYR_FINAL_SPM.pdf $>$ [accessed on December 11th, 2017].

${ }^{10}$ While it is not possible to deal with this within the confines of this chapter, it is acknowledged that responsibility for climate change varies enormously at both state and individual level and that there is a vast literature on this, see, for example, Christopher D. Stone, 'Common but Differentiated Responsibilities in International Law' (2004) 98 American Journal of International Law 276; and Wouter Peeters, A. De Smet, L. Diependaele, S. Sterckx, Robert H. McNeal and Andries De Smet, Climate Change and Individual Responsibility: Agency, Moral Disengagement and the Motivational Gap (Palgrave Macmillan, 2015).

${ }^{11}$ Declaration of the United Nations Conference on the Human Environment, online http://undocuments.net/unchedec.htm, accessed 11 December 2017, preamble, para 7. Discussed in Karen Morrow, 'Sustainability, environmental citizenship rights and the ongoing challenges of reshaping supranational environmental governance' in Anna Grear and Louis Kotze (eds), Research Handbook on Human Rights and the Environment (Edward Elgar, 2015).
} 
at the United Nations Conference on Environment and Development (UNCED) in 1992, states remain, by some measure, the prime movers in international law, not least in the environmental sphere and in human rights contexts they continue to be primarily (though in practical terms not solely) responsible for securing the rights of their citizens. ${ }^{12}$

Remarkably, given the sustainability-dominated context in which it emerged on to the international stage at the UNCED, efforts to address climate change in the 1992 United Nations Framework Convention on Climate Change (UNFCC), ${ }^{13}$ were, in the first instance almost entirely state-centric. ${ }^{14}$ In this largely inter-state context, responsibility, and in particular the concepts of equity and common but differentiated responsibility featured prominently as elements in the international regime from the first, though their practical implementation remains the subject of profound ${ }^{15}$ and ever-more complex ${ }^{16}$ disagreement. In terms of regime reach, the development of participation agenda that also emerged from Rio, prompted in large part by Principle 10 of the Rio Declaration, ${ }^{17}$ coupled with the comparatively swift realisation that the nature and complexity of climate change necessitated a broader stakeholder approach to address it, saw a change in tack in the global climate change regime. This was characterised by an ostensible shift towards greater engagement with a range of non-state actors, though some aspects of the orientation of this move, its depth, and durability, remain open to question. ${ }^{18}$ That said, rationale for broader stakeholder participation in the global climate change regime thus far tends to be couched in a

\footnotetext{
${ }^{12}$ Critiqued for example, in Andrew Kuper (ed), Global responsibilities: Who Must Deliver on Human Rights? (Routledge, 2005) which interrogates the concept of responsibility and examines various means to extend it beyond the state, to non-state actors, including individuals.
}

${ }^{13}$ Available at $<$ http://unfccc.int/files/essential_background/background_publications_htmlpdf/application/pdf/conveng.pdf $>$ [accessed on December 11th, 2017].

${ }^{14}$ See Karen Morrow, 'Climate Change, Major Groups and the Importance of a Seat at the Table: Women and the UNFCC Negotiations' in Robert Schuman Centre for Advanced Studies Working Papers/Policy Paper, The Dominance of Climate Change in Environmental Law: Taking Stock for Rio+20 (RSCAS 2012), available at $<$ http://cadmus.eui.eu/bitstream/handle/1814/24994/RSCAS_2012_67.pdf $>$ [accessed on December 11th, 2017].

${ }^{15}$ See, for example, Kevin R. Gray, Cinnamon Piñon Carlarne, Richard Tarasofsky (eds), The Oxford Handbook of International Climate Change Law (Oxford University Press, 2016).

${ }^{16}$ See, for example, Anita M. Halvorssen, 'Common, but Differentiated Commitments in the Future Climate Change Regime - Amending the Kyoto Protocol to Include Annex C and the Annex C Mitigation Fund' (2007) 18 Colorado Journal of International Environmental Law and Policy 247.

${ }^{17}$ Available at $<$ http://www.un.org/documents/ga/conf151/aconf15126-1 annex1.htm/> [accessed on December 11 th, 2017].

${ }^{18}$ See for, example, Karen Morrow, 'Changing the climate of participation: the gender constituency in the global climate change regime' in Sherilyn MacGregor (ed), Routledge Handbook of Gender and Environment (Routledge, 2017). 
combination of rights-claims and efficacy arguments ${ }^{19}$ (in particular, relating to adaptation) rather than on any explicit notion of human responsibility.

In any case, progress under the global climate change regime remains consistently inadequate to address even relatively conservative (as opposed to worst-case scenario) forecasts of the environmental challenges that we face in this regard. ${ }^{20}$ It is clear that the putative advent of the Anthropocene ${ }^{21}$ demands a paradigm shift in how our understanding of the relationship between humanity and the wider environment. It is also the case that, at least insofar as climate change is concerned, human responsibility is a necessary element of this (re)accommodation process, though we seem set to continue to argue to the point of our extinction as a species as to its extent. In this context, it is imperative that we find ways to engage more effectively with climate change. In consequence, this chapter looks at the notion of human responsibility ${ }^{22}$ as a foil to rights-based approaches that could provide the impetus to kickstart more positive and efficacious engagement with climate change. To this end it interrogates the possibilities of applying an ecologically-informed iteration of a (responsibility-rooted) feminist ethics of care approach in this context. In so doing, it is suggested that, in contradistinction to earlier statements of the ethics of care, environmental issues, far from (at best) constituting a potentially appropriate 'add on' to the human-focussed concepts that populate this moral stance to motivate action, are in fact practically and logically integral to it. That this is type of approach is arguable in principle is borne out by some areas of professional care ethics, for example, considering links between nursing, a core

\footnotetext{
${ }^{19}$ See, for example, the Submission of the Office of the High Commissioner for Human Rights to the $21 \mathrm{st}$ Conference of the Parties to the United Nations Framework Convention on Climate Change, available at $<$ http://www.ohchr.org/Documents/Issues/ClimateChange/COP21.pdf $>$ [accessed on December 11th, 2017].

${ }^{20}$ See UNEP, The Emissions Gap Report 2017: A UN Environment Synthesis Report, United Nations Environment Programme (UNEP), Nairobi, available at $<$ https://wedocs.unep.org/bitstream/handle/20.500.11822/22070/EGR_2017.pdf?sequence=1\&isAllowed=y $>$ [accessed on December 11th, 2017]. For press commentary see, for example, Tom Bawden, 'COP21: Paris deal far too weak to prevent devastating climate change, academics warn', The Independent (8 January 2016) available at $<\mathrm{http}$ ://www.independent.co.uk/environment/climate-change/cop21-paris-deal-far-too-weak-toprevent-devastating-climate-change-academics-warn-a6803096.html $>$ [accessed on December 11th, 2017]; and Fiona Harvey, 'Paris climate deal at risk unless countries step up plans, says watchdog' (16 November 2016) The Guardian, available at $<$ https://www.theguardian.com/environment/2016/nov/16/paris-climate-deal-at-riskunless-countries-step-up-plans-says-watchdog $>$ [accessed on December 11th, 2017].

${ }^{21}$ See Louis Kotze (ed), Environmental Law and Governance for the Anthropocene (Hart, 2017).

22 Discussed in Karen Morrow, 'Of Human Responsibility: Considering the Human/Environment Relationship and Ecosystems in the Anthropocene' in op. cit.
} 
area in this field and its environmental ramifications, when applied to questions of public health. $^{23}$

\section{CLIMATE CHANGE AND THE NEED FOR COHESIVE HUMAN ENGAGEMENT WITH SYSTEMIC ENVIRONMENTAL CONSTRAINTS}

i. The challenge of motivating action on climate change

International environmental law has made some progress on climate change, at least insofar as developing a global regime that facilitates activity (if less action) but, unless explicitly driven by an ultimate, agreed and clearly expressed goal, namely, acting as required to promote the survival and flourishing of humanity, its impetus and impact will inevitably be limited. This is the more so as it is so easy to become bogged down in the many technicalities, unanswerable questions, and irresolvable conflicts of principle posed by climate change, about which we can argue endlessly without necessarily progressing significantly. Under the current trajectory, small successes, including those in the realm of rights, are occasionally to be won, albeit at great pains, when we can focus on practicalities, but absent grasping the necessary super-context, solving the root problem will elude us. Therein however lies the rub. Climate change can be variously classified as a multivalent, 'wicked', or even 'super wicked' problem, ${ }^{24}$ this means it is "multifaceted in every respect [...] incomplete, contradictory, and constantly changing." ${ }^{25}$ Marshall observes that:

[W]icked problems are complex. As a result, there is no point at which one has enough information to make a decision. Instead, wicked problems demand a continuous process of evaluation and redefinition. [...] You can't learn about a wicked problem without trying solutions, but every solution you try creates new consequences and new wicked problems. ${ }^{26}$ [emphasis in the original]

Marshall also notes that, as a result of its multivalency:

\footnotetext{
${ }^{23}$ Lydia Vieira Freitas, Emanuella Silva Joventino, Lorena Barbosa Ximenes, Neiva Francenely Cunha Vieira, Rui Verlaine Oliveira Moreira, 'The ethics of nursing care for environmental crises' (2012) 11(3) Online Brazilian Journal of Nursing 893.

${ }^{24}$ See Burger and Wentz, above n. 5, 2.

${ }^{25}$ See George Marshall, Don't Even Think About It: Why our brains are wired to ignore climate change (Bloomsbury, 2014) 95.

${ }^{26}$ Ibid.
} 
[Climate change $\mathrm{m}]$ ore than any other issue $[\ldots]$ exposes the deepest workings of our minds and shows our extraordinary and innate talent for seeing only what we want to see $[\ldots] .^{27}$

Drawing on a diverse range of behavioural scholarship, Marshall argues that we are in many ways psychologically ill-equipped to deal with climate change, ${ }^{28}$ resulting in a range of nonresponses ranging from "ignorance (not knowing), denial (refusal to know), and disavowal (the active choice not to notice)" ${ }^{29}$ all of which share the same dangerous outcome: disengagement.

The critical question is how to break down a complex problem that, if unaddressed, will escalate to potentially threaten human existence, into something we can not only grasp, but face up to and address? Insofar as climate change is concerned, much disengagement may be expressed as a form of akrasia, defined by Kretz as "weakness of the will or failing to do what one believes to be right." 30 This may be equated, at least in part, with a failure to take responsibility for our actions in both principle and in practice, which prompts questions about the factors contributing to akrasia in the seemingly compelling context of climate change and how best to address them. Marshall argues that, professional (and notably) scientific communication of the issues on which we tend to rely are in fact having limited effect in motivating and even more so, sustaining engagement. To remedy these ills, he posits that: ${ }^{31}$

What climate change really needs are the voices of ordinary people who might not be fluent speakers or skilled orators but can bring an authenticity and genuine sense of common ownership to the issue. ${ }^{32}$

He points to the power of 'stories' in this capacity as a means to engage our emotional brains in processing climate change and as a spur to action. ${ }^{33}$ The necessity of engaging not only the rational but also the emotional parts of the brain to motivate response to complex dilemmas is

\footnotetext{
27 See op. cit., 2.

${ }^{28}$ See op. cit., passim.

${ }^{29}$ See op. cit., 85.

${ }^{30}$ Lisa Kretz, 'Climate Change: Bridging the Theory-Action Gap' (2012) 17(2) Ethics \& the Environment 9.

31 "For the first ten or fifteen years, people's understanding of the underlying science was the single most powerful predictor of their willingness to change their behavior or support government policy.", as notes Marshall, above n. 25, 123, who points out also that '... then the issue became polluted by political and cultural meaning' and '[b]y 2010 only 3\% of people claimed not to grasp climate change', op. cit. 124.

${ }^{32}$ See op cit. 119

${ }^{33}$ See op. cit., 105.
} 
also alluded to by Goralnik and Nelson. ${ }^{34}$ This type of understanding of what fuels human action prompts important questions, including: could addressing stories that reveal the practical implications of human vulnerability to climate change and developing a pragmatic approach to human responsibility founded thereon provide stronger levers for action than arguments drawn from abstract notions of moral responsibility currently do; and could an ethics of care-based approach provide a vehicle whereby to achieve this?

\section{ii. Introducing the ethics of care}

The roots of the ethics of care in feminist theory lie in consideration of the social allocation of reproductive (in the broadest sense of the word, concerning the whole range of life support) activity to women and the deduction of an ethical theory from the situated, dialogic, and relational reasoning that is applied to executing this undertaking. That said, the ways in which this is manifest on a day-to-day basis do vary widely, not least between the developed and developing world, but also on class and other axes. Although a full history of the ethics of care is well beyond the reach of this chapter, a brief sketch of its origins and development will serve to orientate discussion here. The concept emerged in the work of scholars such as Carole Gilligan ${ }^{35}$ and Nel Noddings, ${ }^{36}$ though in this chapter, for reasons of space, discussion will focus on the former scholar, whose approach to developing a gender literate counter to dominant (and in many ways wanting) justice-based ethical theory, in the context of caregiving and the receipt of care, is of particular interest.

Gilligan sought to articulate a counter-hegemonic, care-based approach to moral philosophy, that was as fit to engage with complex real-world problematics as the established justice paradigm, and which is particularly apposite for present purposes. When asked to define an ethics of care, Gilligan has described it as "grounded in voice and relationships, in the importance of everyone having a voice, being listened to carefully (in their own right and on their own terms) and heard with respect. An ethics of care directs our attention to the need for responsiveness in relationships (paying attention, listening, responding) and to the costs of

\footnotetext{
${ }^{34}$ See Lissy Goralnik_and Michael Nelson, 'Forming a Philosophy of Environmental Action: Aldo Leopold, John Muir, and the Importance of Community’ (2011) 42(3) Journal of Environmental Education 181.

${ }^{35}$ See, for example, Carole Gilligan, In A Different Voice (Harvard University Press, 1982).

${ }^{36}$ See, for example, Nel Noddings, Caring: A Feminine Approach to Ethics and Moral Education (University of California Press, 1982).
} 
losing connection with oneself or with others. Its logic is inductive, contextual, psychological, rather than deductive or mathematical." 37

The strongly feminist grasp of the particularised and perspectival nature of knowledge that Gilligan's work imports as central elements of her ethical framework has enormous potential to re-shape how we think about moral issues. Furthermore, the observational and dialogic nature of knowledge that care fosters and the responsibility-centred notion of power that follows from it can be viewed as extending beyond the human relationships/interrelationships that Gilligan concerns herself and which form its centre, As Gilligan observes:

[T]he ethics of care starts from the premise that as humans we are inherently relational, responsive beings and the human condition is one of connectedness or interdependence. ${ }^{38}$

\section{iii. Framing the Ethics of Care Through an Eco-feminist Lens}

Re-framing the ethics of care to accommodate environmental issues is facilitated by the fact that the core elements of such an approach sits well with eco-feminist philosophies. As Stephanie Lahar puts it, most versions of ecofeminism are, accommodatingly, concerned with "the interrelationship and integration of personal, social and environmental issues and the development of multidirectional political agendas and actions."39

Lahar suggests a framework for considering ecofeminism that can arguably be applied to an ecological iteration of the ethics of care, drawing on the potential for strong commonalities between the two areas and deploying the former to support an ecologically expanded iteration of the latter. First, Lahar argues that eco-feminism can be framed as a moral theory, an approach that Galligan also applies to the ethics of care, and which is rooted in like fashion. Lahar states that:

[A] moral theory must emerge out of a felt sense of need and personal connection with the issues at hand, not just out of an abstract process of reasoning. ${ }^{40}$

\footnotetext{
37 'Gilligan Interview', June 21st, 2011, available at <https://ethicsofcare.org/carol-gilligan/> [accessed on April 4th, 2018].

38 Ibid.

${ }^{39}$ Stephanie Lahar, 'Ecofeminist Theory and Grassroots Politics' in Karen J. Warren (ed), Ecological Feminist Philosophies (Indiana University Press, 1996) 2.

${ }^{40}$ See op. cit., 9.
} 
Lahar's specific objective is to develop ecofeminism as an "action-guiding ethical theory" 41 and she identifies the key task here as "incorporating the integrity of individual and collective realities is an expanded concept of nature that we, as gendered human beings, can then find our place in." 42 Second, and relatedly, Lahar tasks the philosophical approach developed with integrating humanity and nature. Lahar's third and fourth considerations relate to the practicalities of developing ecofeminism as a dynamic process driven by those who theorise and deploy it; and which maintains an "active political and participatory emphasis that is both deconstructive ... (reactive to current injustices) and reconstructive (proactive in creating new forms of thinking and doing). $" 43$

Whilst applying the first two elements of Lahar's approach to the ethics of care requires a case to be made, which will be developed below, the latter considerations are fairly central to feminist philosophy and ethics more generally, albeit with a strong praxis element that is characteristic of ecofeminism. These are however already effectively shared with the iterative, experience-driven, and paradigm-challenging aspects of an ethics of care approach.

As the ethics of care acknowledges, the human condition is indeed concerned centrally with human relationships, but this is not an exclusive focus and in ecological terms these connections are themselves grounded in our relationship with the natural world. The concepts of connection, knowledge, power, and responsiveness that characterise Gilligan's ethics of care can then and indeed must also be applied to the human relationship with nature because our interdependence with it too is pervasive and inevitable. Our related responsibility to care for the environment in return for its nurturing of our species, it is founded not only on moral grounds, but as we now recognise with a new clarity, on survival, the most practical of motivations. We now, belatedly, recognise (or recall ${ }^{44}$ ) that our very survival as a species is (inter)dependant with that of the biosphere, and in light of this it behoves us to urgently fashion a new responsive dialogue with the world around us.

\footnotetext{
${ }^{41}$ See op. cit., 10.

42 Ibid.

${ }^{43}$ See op. cit., 8 .

${ }^{44}$ See Ian D Rotherham, Eco-History: An Introduction to Biodiversity and Conservation (White Horse Press, 2014) which points to the ill-recalled environmental literacy of generations past; and Benjamin J. Richardson, 'The Ties that Bind: Indigenous Peoples and Environmental Governance' (2008) Comparative Research in Law \& Political Economy. Research Paper No. 26/2008, available at $<$ http://digitalcommons.osgoode.yorku.ca/clpe/197> [accessed on May 8th, 2018], which discusses the complexities of indigenous approaches to environmental governance as alternates to the dominant paradigm.
} 
While nature cannot 'speak' for itself, the same is true for many of the human subjects of care (for example, infants and those operating under a range of disabilities); in these cases, and where nature too is concerned, this does not preclude dialogue, as human agents can speak on behalf of those/that which cannot. ${ }^{45}$ Furthermore, at a very basic level, observation often signals that human activity is impinging on the ability of species and ecosystems to flourish. ${ }^{46}$ Ultimately then, morality, philosophy, and human advocacy aside, environmental degradation and deterioration speak volumes in themselves in ways that, regardless of their often-imperceptible origins, become manifest and measurable. ${ }^{47}$ Both morally and practically then, it has never been more imperative that we grasp the import of care in observing, understanding, and acting on nature's limits, ${ }^{48}$ with which our own are intimately enmeshed, rather than blindly continuing to pursue a supposed and ultimately illusory mastery ${ }^{49}$ over non-human nature, on which we rely.

iv. The potential of the ethics of care to extend to the public domain

Recognition of the potential to extend the ambit of the ethics of care approaches is not novel, as while well-established in feminist theory, the approach is not siloed therein. The ethics of care has, for example, often been applied to the 'caring professions', ${ }^{50}$ and has been rolled out into with some success in relation to moral philosophy ${ }^{51}$ but this chapter argues, in common with emerging scholarship in the latter area, ${ }^{52}$ that its practical application has the potential to extend much more widely and in particular to be applied to human/environment

\footnotetext{
${ }^{45}$ Discussed for example, in the ground-breaking Christopher Stone, 'Should Trees Have Standing? — Towards Legal Rights for Natural Objects' (1972) 45 Southern California Law Review 450.

${ }^{46}$ See for example work on earth-centred governance such as Thomas Berry, 'Ten Principles for Jurisprudence Revision' in Thomas Berry (ed), Evening Thoughts Reflecting on Earth as Sacred Community (Sierra Club Books, 2006).

${ }^{47}$ Steffen et al., above n. 3 .

48 Ibid.

${ }^{49}$ Val Plumwood, Feminism and the Mastery of Nature (Routledge, 1993).

${ }^{50}$ See, for example, Tula Brannelly, Lizzie Ward, and Nicki Ward (eds), Ethics of Care: Critical advances in international perspective (Policy Press, 2015); and Marita Nordhaug and Per Norvedt, 'Justice and Proximity: Problems for an Ethics of Care' (2011) 19 Health Care Analysis 3.

${ }^{51}$ See, for example, Virginia Held, The Ethics of Care: Personal, Political, and Global (Oxford University Press, 2005).

${ }^{52}$ See, for example, Fiona Robinson, The Ethics of Care: A Feminist Approach to Human Security (Temple University Press, 2011); Lissy Goralnik, Kelly F. Millenbach, and Michael P. Nelson, 'An Environmental Pedagogy of Care: Emotion, Relationships, and Experience in Higher Education Ethics Learning’ (2012) 35(3) Journal of Experiential Education 412; and Freitas et al., above, n. 23.
} 
relationships in the fullest sense. In this regard, there is an important strand of scholarship promoting a broad application of the ethics of care, reaching beyond its ostensibly private sphere origins, ${ }^{53}$ which will help to ground discussion.

For present purposes this will be represented by Helena Olofsdotter Stensota's public ethics of care, which offers particular promise for the purposes of this chapter. ${ }^{54}$ In developing her approach, Stensota builds to good effect on aspects of Joan Tronto's much earlier work in the field, wherein the latter observed that care is something that extends its reach to all human endeavour, applying to "everything we do to maintain and reproduce ourselves and "the world" so that we can live in it as well as possible." 55 While Tronto was criticised by some for taking too wide an approach to care, her view is in fact a logical one, as the boundaries of care and its ethics are not confined to the family responsibilities, or even the 'caring professions' of its origins and early application, but rather, as Bowden observes, open to a whole range of "ethical possibilities." 56

Stensota's public ethics of care, is grounded on four core notions. These comprise: first, interdependence-which in common with my own view sees humans "as being interdependent at all points in time, as we are connected through relations with other people or our surroundings — without which we would most definitely die." 57

Second, Stensota points to the significance of relations in her approach to care, focussing on "establishing, nurturing, sustaining and protecting relationships of different kinds." 58 Here though I part company with Stensota to a degree as, while she invokes protection as being geared toward the goal of 'not-hurting' this seems to me to be a rather limited definition of the concept and I would instead regard this element of an ethics of care approach in more ambitious terms, in concert with Thomas Berry, ${ }^{59}$ as promoting the flourishing of the object of care.

\footnotetext{
${ }^{53}$ See for example, Peta Bowden, Gender-sensitive Ethics (Taylor and Francis, 1996).

${ }^{54}$ Helena Olofsdotter Stensota, 'Public Ethics of Care - A General Public Ethics' (2015) 9(2) Ethics and Social Welfare 183.

${ }^{55}$ See Joan Tronto, Moral Boundaries, A Political Argument for an Ethic of Care (Routledge, 1994) 103.

${ }^{56}$ See Bowden, above n. 53, 197.

${ }^{57}$ See Stensota above, n. 54, 189-190.

${ }^{58}$ Ibid.

${ }^{59}$ See Berry, above n 46, 149-150.
} 
Third, Stensota's approach features the concept of responsibility as centrally important, and she points to its assumption as crucial, but to a lawyer's reading her approach seems in fact to be more concerned with its recognition, which is not quite the same thing. Nonetheless Stensota does clearly articulate responsibility as "attached to the handling of problems." ${ }^{60} \mathrm{In}$ this context Stensota characterises the environment as a 'new' problem to be dealt with by the public ethics of care. While one may contest the claim to novelty, the application of an ethics of care approach to environmental issues certainly raises exciting possibilities. ${ }^{61}$

The fourth element of Stensota's construction of the ethics of care comprises context sensitivity, wherein she promotes the situated rather than abstract treatment of issues, ${ }^{62}$ though she tends to equate this with a localised agenda. She states that public ethics of care "may function so as to strengthen environmental concerns in every discussion and deliberative talk regarding policies that affect the local context and green environment." ${ }^{\prime \prime}$

This approach has some merit and would adequately represent the most straightforward elements of an ethics of care approach toward environmental issues. However, if this represented the full scope of the applicability of such an approach it would be of rather limited utility in seeking to address a multivalent issue like climate change, which while it has local manifestations, is also expressed at every other level of society, extending ultimately to the global. Below, the rationale for a much broader spatial scope for an ethics of care approach to the environment is developed, positing its potential applicability to all planes of human endeavour.

With this in mind Stensota's limitation of the sphere of application of the public ethics of care to what she terms the 'green environment' is also problematic Whilst this area of concern certainly falls within an ethics of care approach, it takes too narrow a view of the scope of human influence and in consequence, the morally imperative realm of human responsibility. If, as is now abundantly apparent, we can shape and distort the environment in all its forms and at all levels, from the microscopic to the global, to human ends, then we need to rethink the ambit of care. We depend on the environment for our own flourishing as a species and the biosphere increasingly depends on us for its flourishing (or otherwise) and any human

\footnotetext{
${ }^{60}$ See Stensota, above n. 54, 190.

61 Ibid.

${ }^{62}$ See op. cit., 191.

${ }^{63}$ See op. cit., 194. Stensota goes on to refer to local spatial planning and local environmental regulation in this regard. See op cit., 195-196.
} 
activity that generates substantial environmental impact at any scale is therefore ripe for reconsideration through the lens of care.

In the alternative to Stensota's argument for a 'public' ethics of care, there are particular considerations that serve to render the public/private divide at least insignificant, or even illusory, in environmental contexts. Thus, while the origins of the ethics of care are located in the private domain, this is not decisive in the context of its putative application to environmental behaviours. This is because, as Dobson observes, where the environment is concerned, private acts have public implications. ${ }^{64}$ Thus, as Barry states "when considered from an ecological point of view, [the private sphere] moves from being a 'non-political' to a political site of activity." 65

Another way of looking at this issue is as apposite for the application of the well-worn feminist saw that the personal is political. ${ }^{66}$ If we take these points to their logical conclusion, then carrying out the day to day business of inter-human care, reproduction in its broadest sense, pertaining to the activities that sustain our lives and enable human flourishing, ultimately depends on the biosphere being in a condition that is conducive to our ends. In this view the environment functions as an essential object of care and human activity in all its many guises is ripe for consideration from an ethics of care perspective.

\section{CONCEIVING AN ENVIRONMENTAL ETHICS OF CARE AS A DRIVER FOR A PARADIGM SHIFT IN THE HUMAN/ENVIRONMENT RELATIONSHIP}

\section{i. The Ethics of Care as a Potential Corrective to the Paradigm of Mastery}

Embracing an ethics of care-oriented approach to the relationship between humanity and the rest of nature arguably has the potential to secure human survival as a minimum, and if vigorously pursued, to facilitate human flourishing. In part this promise lies in consciously

\footnotetext{
${ }^{64}$ See Andrew P. Dobson, Citizenship and the Environment (Oxford University Press, 2003) 135.

${ }^{65}$ See John Barry, 'Vulnerability and virtue: Democracy, dependency and ecological stewardship' in Bob A. Minteer and B. Pepperman Taylor (eds), Democracy and the Claims of Nature (Rowman and Littlefield, 2002) 147-148.

${ }^{66}$ See Linda Napikoski, 'The Personal Is Political: Where Did This Slogan of the Women's Movement Come From? What Does It Mean?', available at <https://www.thoughtco.com/the-personal-is-political-slogan-origin3528952> [accessed on April 9th, 2018].
} 
recalling/recognising and acting upon the (re)discovered reality ${ }^{67}$ of humanity as situated within, rather than above nature. This grounding in ecological realism seems to offer a more effective direction of travel than a preoccupation with the assertion of rights, which significant as it may be in principle, often seems far divorced from practicalities. It is worth noting that, while applying an ethics of care line to the human/environment relationship would represent a considerable shift in perspective, it would be an evolutionary rather than a revolutionary move at base, shifting the paradigm rather than introducing an entirely new one, in that its orientation remains anthropocentric in nature.

An ethics of care approach does however, does offer a considerable advance on the current position, eschewing a purely instrumental view of non-human nature, as it positions humanity as ecology suggests: as an integral part of the web of relationships that comprise the biosphere. Thus, an ethics of care-oriented approach offers a potential correction to the terminal hubris of what Plumwood eloquently terms the paradigm of mastery, drawn from Descartes and under which nature has come to be routinely viewed and treated "in instrumentalist terms as available without constraint for annexation and normalisation to fit human needs, as a mere thing for human use." 68

The results of following the paradigm of mastery to its logical conclusion are arguably now beginning to become fully manifest as we enter the Anthropocene, as burgeoning human population and the increased sophistication of our science and technology serve to intensify rates of resource use and the quantity and complexity of the pollution we create as a byproduct of pursuing our various endeavours. Core impacts of the pursuit of mastery include, an over-indulged, vastly privileged minority in the human population, disconnected from the natural world, whose insatiable and endless drive to accumulate and consume places the earth-system under pressure as never before, as we bend nature to our short term aims in ways that profoundly damage the natural world.

At the same time, the pursuit of mastery takes an inequitable toll on much of humanity, and in particular the poorest and the most vulnerable, who disproportionately shoulder the adverse impacts of the environmental degradation that the mechanics of mastery generate but benefit little from the short-term advancement that it generates-climate change providing a

\footnotetext{
${ }^{67}$ Arguably something recognised widely historically, see, for example, Rotherham, above n. 44; and now underlined by contemporary observers, see, for example, Karen Litfin, 'The gendered eye in the sky: Feminist perspectives on earth observations satellites' (1997) 18(2) Frontiers 26.

${ }^{68}$ Plumwood, above n. 49, 110.
} 
prime example of this. My central contention in arguing for an environmental iteration of an ethics of care is that sustainable care for ourselves and other humans necessarily requires care for the environment in which we are enmeshed and on which we depend. In this context, ethics of care approaches offer an alternative basis upon which to proceed to the toxic paradigm of mastery and one that speaks not only to local experience of ecological limits, but which ultimately has the potential to extend its reach to address transgressing the safeoperating spaces for humanity ${ }^{69}$ at regional and planetary boundary levels.

While, as considered above, scholarship on the ethics of care tends to focus on its ethical locus $^{70}$-important as that is (and applicable as it would be in the current context) - , I want at this point to focus on another, underexplored aspect of the ethics of care that is, I think crucial in the context of climate change. On re-examination the ethics of care reveals profound truths about the various sources of human vulnerability and agency. Here there are important commonalities between ethics of care approaches and feminist political ecology that support the contention that the former is not only salient to but essential in framing a realistic understanding of the human/environment relationship. There are many views of what form the core constituents of an ethics of care, I argue that the key composite elements which can be distilled from combining the ethics of care and ecological context to form an environmentally-rooted ethics of care constitute: relationships-both inter-human and human/environmental, characterised by vulnerability, connection and responsiveness; and care prompted and promoted through a combination of agency and responsibility.

ii. Relationships (Human and Environmental): Vulnerability, Connection, and Responsiveness

The relationships which are central to an ethics of care perspective hinge on the concept of human vulnerability. In the first instance, care is owed to human dependants in recognition of their vulnerability. At the same time, and enmeshed with this very intimate human interconnection, human vulnerability more generally is the product of our actual (and for future generations contingent) embodiment, ${ }^{71}$ being both in and of our environment.

\footnotetext{
${ }^{69}$ See Steffen et al. above n. 3.

${ }^{70}$ See, for example, the 'four attributes' identified in Joan C. Tronto, in 'An ethic of care', in Ann E. Cudd and Robin O. Andreasen (eds), Feminist theory: a philosophical anthology (Blackwell, 2005).

${ }^{71}$ A complex and rapidly evolving area of academic study in itself, extending to both biological and nonbiological entities see, for example, Tom Quick, Kerstin Dautenhahn, Chrystopher L. Nehaniv and Graham
} 
Vulnerability here is particularly complex, operating simultaneously in situating humanity in an environment that ultimately renders us vulnerable, yet at precisely the same time that very environment is, now as never before, vulnerable to the impacts, both intended and unintended, of the exercise of human agency. Barry, in his discussion of ecological stewardship, makes observations that are also apposite in the current context, pointing to the need to recognise that we are entangled in "webs of dependence and vulnerability, those relationships between people, planet, and the two together, creating a community of dependence and vulnerability, the most appropriate attitude toward which is a disposition of responsibility, care, and mindfulness. ${ }^{72}$

That we are intimately enmeshed in multiple layers of human relationships and are simultaneously in complex, multi-layered, and multi-faceted connection with the biosphere, ${ }^{73}$ with all that these realities and the multifarious interactions between them entails in terms of survival and flourishing, is seemingly obvious, yet this fact (at best) exerts extremely limited influence on currently dominant patterns of human behaviour vis-à-vis the environment. ${ }^{74}$ It is also the case that the embodiment that we experience as humans is (amongst many other determining factors) gendered, and in part shaped by socially allocated daily work and caring responsibilities that are substantively distinct between the sexes. ${ }^{75}$ Vulnerability in both human and broader environmental contexts, is also in part socially imposed by human structures, and these too feature significant dimensions shaped by patriarchal structures and applied to women. In an environmental context the application of this insight is usefully underlined in feminist political ecology and the observation that "there are real, not imagined, gender differences in experiences of, responsibilities for and interests in "nature" and environments, but that these differences are not rooted in biology per se. Rather, they derive from the social interpretation of biology and social constructs of gender, which vary

Roberts, 'The Essence of Embodiment: A Framework for Understanding and Exploiting Structural Coupling Between System and Environment', Computing Anticipatory Systems (2000) CASYS'99 — Third International Conference. AIP Conference Proceedings, Volume 517, 649.

${ }^{72}$ See Barry, above n. 5, 146.

${ }^{73}$ See, for example, Val Plumwood, 'Ecological Ethics from rights to recognition: multiple spheres of justice for humans, animals and nature' in Nicholas Low (ed), Global Ethics and Environment (Routledge, 1999).

${ }^{74}$ See, for example, Morrow, above, n. 22; and Plumwood, above n. 49.

${ }^{75}$ See B. Agarwal, 'Engendering the Environment Debate: Lessons from the Indian Subcontinent' CASID (Center for the Advanced Study of International Development) Distinguished Lecture Series, Discussion Paper 8 (Michigan State University, 1991). 
by culture, class, race and place and are subject to individual and social change." (emphasis in the original) ${ }^{76}$.

Rocheleau et al. identify the core concerns of feminist political ecology as "survival; the right to live and work in a healthy environment; the responsibility to protect habitats, livelihoods, and systems of life support from contamination, depletion [...] and destruction; and the determination to restore or rehabilitate what has already been harmed."77

These observations, in foregrounding the imperative of survival and the centrality of responsibility in this endeavour, demonstrate important areas of commonality with the ethics of care. The salience of social vectors in shaping human activity features prominently in the context of care too, notably in Tronto's work, identifying other significant influencing factors, beyond gender, notably race and class. ${ }^{78}$ The fit with climate change is apparent as its impacts too are now widely recognised as gendered ${ }^{79}$ and aggravated by poverty and other societal constructs and ills. ${ }^{80}$

While human relationships are central to the ethics of care and may be viewed as founded on respect for human vulnerability and a response of connection to it as motivational drivers, they cannot logically be regarded as the sole manifestation of relationship, vulnerability, or connection having salience for it. The ethics of care is sufficiently malleable to extend its reach, Stensota for example argues for a "notion of the ethics of care that is so broad as to encompass policies that we hitherto have not considered as care-relevant" ${ }^{\text {" }}$ and, as discussed above, she views environmental issues as (at least to a degree) falling within this expanded approach. While I agree with her willingness to take an expansive approach to care, and to view the environment as within its remit, my approach to the issue is rather different.

Insofar as encompassing environmental considerations within care is concerned, rather than requiring an expansion of what is care-relevant, this instead involves a recognition that the

\footnotetext{
${ }^{76}$ Diane Rocheleau, Barbara Thomas-Slayter and Esther Wangari, 'Gender and the environment: A feminist political ecology perspective' in Diane Rocheleau, Barbara Thomas-Slayter and Esther Wangari (eds), Feminist Political Ecology (Routledge, 1996) 4.

${ }^{77}$ See op cit., 6.

${ }^{78}$ See Joan Tronto, 'Beyond Gender Difference to a Theory of Care' (1987) 12(4) Signs 644.

${ }^{79}$ See, for example, Gotelind Alber, 'Gender, Cities and Climate Change', Thematic report prepared for Cities and Climate Change Global Report on Human Settlements (2011), available at $<$ https://unhabitat.org/wpcontent/uploads/2012/06/GRHS2011ThematicStudyGender.pdf $>$ [accessed on December 13th, 1017]; and Chris Cuomo, 'Climate Change, Vulnerability and Responsibility' (2011) 26(4) Hypatia 690.

${ }^{80}$ See, for example, Alber, op. cit.

${ }^{81}$ See op. cit., 185.
} 
environment is in fact foundational to the ethics of care and is therefore inherent in it. This contention is founded on the interdependence of humanity and the environment which makes the environment both a necessary subject and object of care. The environment is not therefore only case-relevant to certain human care relationships or aspects thereof; rather it is integral to all inter-human care. Therefore, an environmentally rooted ethics of care does not in fact involve an expansion of care, but instead acknowledges the full ramifications of human situatedness in and our interdependence with/on the environment as the ultimate underpinning of the relational nature of all aspects of the human position/predicament.

Relationship in the ethics of care then involves both human and environmental dimensions and the array of interactions between them, but even this does not fully encapsulate the complexity of what is in play. Marian Barnes argues that relationships are "essentially spatial." ${ }^{\prime 2}$ I take the view that relationships are partially spatial, but only in the first instance, and that they also possess temporal dimensions (considered below) that are highly significant. That said, the spatial aspect of relationships of care is centrally important and worthy of fuller consideration as a foundational issue.

In principle, an ethics of care could be approached in a manner akin to Wimberley's construct of nested ecologies, ${ }^{83}$ which he describes as comprising: "an interlocking set of systems that begin at the level of the sense and extend to encompass families, groups, communities, ecosystems, the biosphere, and beyond into the unfathomable reaches of the cosmos." 84 Wimberley applies the idea of 'nesting' as invoking "an integrated whole progressively based upon personal, social, environmental and cosmic ecologies." 85 An ethics of care also represents a concept that can be addressed through systems theory and viewed as multilayered, and as radiating outwards. Thus, it begins with self-care and extends centrifugally, ${ }^{86}$ applying (albeit in serially diminishing measure) to our families/ living units, our various and multi-layered communities, and ultimately to our species.

\footnotetext{
${ }^{82}$ See Marian Barnes, Care in Everyday Life: An Ethic of Care in Practice (The Policy Press, 2012), in particular, Chapter 6.

${ }^{83}$ See Edward T. Wimberley, Nested Ecology: Understanding the Place of Humans in the Ecological Hierarchy (Johns Hopkins University Press, 2009).

${ }^{84}$ See op. cit., 4.

${ }^{85}$ Ibid.

${ }^{86}$ See, for example, J. R. Torney-Purta, H. Lehmann, H. Oswald, and W. Schulz, Citizenship and education in twenty-eight countries: Civic knowledge and engagement at age fourteen (The International Association for the Evaluation of Educational Achievement, Amsterdam, 2001).
} 
Wimberley's nested ecologies also share functional links to the notion of care, expressed in the imperative need to address "our species-derived need to principally care for self and others like us, and thereafter to understand that our future on the planet is entirely dependent upon our readiness to extend care and consideration for all around us that is not human but upon which our very existence depends." ${ }^{87}$ Practically and ethically ${ }^{88}$ nested layers of caring are foundationally based in the environment which we are both in and of is a matter of necessity, not choice.

If we accept that all aspects of care are ecologically situated, then its spatial aspects too are necessarily multi-layered. In much the same way as Wimberley viewed human world views being located in interlocking natural, personal, and social ecologies, both human relationships of care and our care relationship with the environment, invoke a similarly nested approach. Thus, while the prime locus and focus of care inevitably lies in our nearest human concerns, it is also the case that there is no sustainable, viable care for one's dependants that can be detached from our immediate surroundings, which are in turn dependent on wider ecosystems, and ultimately on the functionality of the biosphere.

To be feasible then, an ethics of care must acknowledge that human and environmental concerns are inherently, intimately, and inseparably entangled. While the human and environmental dimensions of the sphere of concern, caring, capacity, and responsibility will focus most closely on the personal/family unit, determined in part by proximate spatial connection, they are not inherently limited to this domain and radiate outwards beyond this intimate starting point. Indeed, it is arguable that care-based ethics must extend beyond the particular (though admittedly in more dispersed forms as knowledge, involvement, and the potential for agency dwindle with distance) to embrace the variously composed contexts in which immediate personal care concerns are situated. The further reach of the spheres of care beyond the personal/familial/quasi familial may begin with local communities but has the potential to extend spatially, invoking (all or any of) local, national, regional, or global dimensions. Some aspects of a care focus will clearly be geographically anchored and constrained and focus on those perceived as 'near' to us, but they may still extend beyond the

\footnotetext{
${ }^{87}$ See Wimberley, above n. 83, 205.

${ }^{88}$ See Shagbark Hickory (J. Cheyney), 'Everyday Environmental Ethics as Comedy and Story: A Collage' (2003) 8(2) Ethics and the Environment 80, which draws on Wendell Berry's concept of nested communities (Wendell Berry, The Unsettling of America: Culture and Agriculture ( Sierra Club Books, 1977)) and identifies "kindly use" of environmental resources as dependant on "the individual being nested in human community, human community being nested in agriculture (i.e. human use of the community of life) and agriculture being nested in wildness," 94.
} 
immediate, other spheres of care will not be constrained in this way and may be regional and even potentially global (such as virtual communities of interest expressed through the internet) in reach and concerned with issues that affect large sections of humanity or humanity as a whole. This observation is prompted in part by an important aspect of planetary boundaries thinking, which seeks to link ecology and environmental science explicitly with society, and that, while its particular concern lies with global systems, is cognisant of the local and regional elements that comprise them. ${ }^{89}$ These ideas of connection, interconnection and embracing the potential multi-scalar implications of care raise interesting and important issues that go well beyond the confines of this chapter but which certainly warrant further research.

While relationships as understood in an ethics of care setting must in the first instance be understood to be spatial in nature, as alluded to above, they are also enmeshed in temporal dimensions as suggested by Pulcini's argument, digested by Stensota, that care "provides the only framework on which to base solidarity with future generations." 90 While this may be overstating the case (positing it as the only option being a very ambitious claim), the ethics of care approach does indeed provide a potentially viable basis for a principled approach to forward-looking thought and action. Here, as is the case with the spatial dimensions of care, the increasing imponderability of care priorities as we move further and further from our own time, suggests a level of care that, while founded on a minimum of ensuring the well-being of succeeding generations, will diminish the further into the future we gaze, as our responses become increasingly grounded on speculation. However, temporal dimensions of the ethics of care also need to look back to appreciate the constraints placed on our ability to exercise care by our predecessors, not least because it is crucial to grasp the importance of how, in the chain of human history, behaviours and decisions at one point in time can circumscribe the realm of viable action in future, a lesson that must be applied to the consequences of present (in)action on climate change.

iii. Agency and Responsibility: Prompting and Promoting Care

\footnotetext{
${ }^{89}$ See Steffen et al., above n. 3.

${ }^{90}$ See Elena Pulcini, Care of the World: Fear, Responsibility and Justice in the Global Age (Springer, 2009), quoted in Stensota, above n. 54, 186.
} 
The consideration of embodiment that requires the recognition of vulnerability also prompts reflection on the impacts of human agency on planetary systems and the constraints that planetary boundaries place upon us in this regard. While agency is a species-wide attribute, there is an enormous degree of variability in its strength and impact between classes of human actor. Agency too is however fundamentally gendered, and this can serve to mask the importance of care in this guise. Thus, while women's caring roles often bring with them considerable environmental responsibility, garnering grounded knowledge of the environment, requiring skilled reading of conditions and responsive practices toward them, rather than this quotidian knowledge being seen as significant and a source of power, it is, for the most part, underplayed or disregarded..$^{91}$

Recognising human agency is a key mechanism of empowerment whereby responsibility can enveloped in the context of care and it is very telling that in the context of climate change, while women's vulnerability has long been recognised, that their agency has only begun to come to the fore much more recently. ${ }^{92}$ Adopting Kretz's approach, to questions of addressing what she terms the 'theory-action gap,' responsibility fits well with an ethics of care approach, as she points out that responsibility is "not about identifying who to blame and therefore hold accountable, an approach which enables one to ostensibly absolve oneself of responsibility. Responsibility is to be conceptualized in a forward looking, positive way-it is about taking responsibility through identifying how to help and acting accordingly." 93

Stensota adds a further useful dimension to the concept of responsibility when she points to its potential to support a "more problem-related view and [...] provide ways to incorporate contextual considerations" 94 into human endeavours. Rocheleau et al. however observe the limitations imposed by dominant gendered approaches to responsibility inherent in the recognition (or lack thereof) of care-based roles:

We recognize gendered environmental rights of control and access as well as responsibilities to procure and manage resources for the household and the community. These rights and responsibilities may apply to productive resources [...] or to the quality

\footnotetext{
${ }^{91}$ For a much fuller discussion of gender and the importance of situated knowledge and lived experience in adding to the sum of our ability to engage with environmental issues see Karen Morrow, 'Perspectives on Environmental Law and the Law Relating to Sustainability: A Continuing Role for Ecofeminism?' in Andreas Philippopoulos-Mihalopoulos (ed), Law and Ecology: New Environmental Foundations (Routledge, 2011).

${ }^{92}$ See, for example, CBD, UNCCD, UNFCCC, 'The Rio Conventions: Action on Gender' (2012), available at $<$ http://unfccc.int/resource/docs/publications/roi_20_gender_brochure.pdf $>$ [accessed on December 13th, 1017].

${ }^{93}$ See, for example, Kretz, above n. 30,16-17.

${ }^{94}$ See Stensota, above n. 54, 184.
} 
of the environment. In addition to the gender division of resources, there is a gender division of power to preserve, protect, change, construct, rehabilitate, and restore environments and regulate the actions of others. ${ }^{95}$

Relatedly, while a local contextualisation and recognition of women's care and agency is essential, ${ }^{96}$ so too is an understanding of the impact of global issues on national and local contexts (and indeed vice versa) which also have impacts on agency and which, as the boundaries between the various levels of human endeavour become increasingly blurred have increasingly important implications. ${ }^{97}$ Rocheleau and her co-authors identified a number of important themes common to treatment of gender and environment worldwide drawn from multiple case studies; key among them being that both environmental science and the international environment movement have been fundamentally 'cast in the domain of men', mostly from the developed world, and have tended to ignore/devalue grassroots contributions, including, 'daily management of the living landscape' which served to exclude women from the power that normally accompanies responsibility. ${ }^{98}$ Concomitantly, they observe that the status accorded to women and to caring functions tends to be low:

Women are perceived in terms of their roles as providers of labor and tenders of the household, rather than as farmers and managers of the land or of other significant means of livelihood. [implying the...] notion that women's labor is infinitely expandable, and that their domestic responsibilities (whether of a productive or reproductive nature) are not particularly significant. ${ }^{99}$

Thus, while women are acknowledged as being responsible for both human and environmental care functions, that responsibility is then largely divorced from power over the resources that they tend and rely upon and does not result in recognition and harnessing of their agency in caring for their households, communities, ${ }^{100}$ and the environments that sustain them.

\footnotetext{
${ }^{95}$ See Rocheleau et al., above n. 76, 10.

${ }^{96}$ See op. cit., 299.

${ }^{97}$ See op. cit., 300. See also Andrea Nightingale, 'The nature of gender: work, gender and the environment', (2006) 24 Environment and Planning D: Society and Space 165.

${ }^{98}$ See Rocheleau et al., above n. 76, 6.

${ }^{99}$ See op. cit., 298.

${ }^{100}$ See for example, Barbara Thomas-Slayter, Esther Wangari, and Diane Rocheleau, 'Feminist political ecology: Cross-cutting themes, theoretical insights, policy implications’ in Rocheleau et al. above n 76.
} 


\section{NOT SO MUCH A CONCLUSION, AS A CALL TO ACTION...}

While, as Rocheleau et al. observe, caring has long been devalued and readily open to criticism as an essentialised attribute of women, recent research suggests that care is in fact less easy to dismiss in this way, as it appears to be an integral part of humanity's psychological make-up. ${ }^{101}$ This understanding could facilitate the reframing of the ethics of care to provide the necessary sense of perspective and impetus to promote broader human engagement with environmental constraints and specifically with climate change. This can be achieved by combining a science-based grasp of what human vulnerability means and how it applies to all of us, with an appreciation of the full scope of agency, harnessed to responsibility could contribute that socially enforced constraint that would promote planetary care in order to ameliorate the existential threat of climate change. Care for the life support system on which we rely is on one level, as it has always been, a matter of morality but ecological realism now suggests that it is now rapidly becoming a matter of necessity, not choice, if human self-care is to be realizable and sustainable. If both ethics and practicality point to the utility of adopting an ethics of care in our dealing with the environment this presents interesting possibilities, not least in tackling the atomism of modern life, recognising that:

The myth of the individual has left us disconnected, lost, and pitiful ${ }^{102}$

Relationship, (re)connection, with one another and with the non-human environment, and taking responsibility for the central human concerns that this entails is becoming imperative. Taking meaningful action on climate change is something that we can no longer allow states to deflect on to one another, like a game of pass the parcel at a children's party: if we continue to play as we have done, we will all lose. Nor can we continue as individuals to shirk our own responsibilities and expect state action alone to save us. Anthropogenic climate change truly is a human responsibility in the fullest sense-we are implicated at all levels of society. ${ }^{103}$ We will ultimately live or die as a species, by our ability to respond to the

\footnotetext{
${ }^{101}$ See Daniel Engster, 'Care in the state of nature: The biological and evolutionary roots of the disposition to care in human beings' in Daniel Engster and Maurice Hamington (eds) Care Ethics and Political Theory (Oxford University Press, 2015).

${ }^{102}$ See Kate Tempest, 'Let Them Eat Chaos' (Caroline International P\&D, 2016).

${ }^{103}$ See Steffen at al., above n. 3.
} 
Anthropocene, not only as expressed in understanding the systemic threats that we create ${ }^{104}$ but also moving beyond endless talking about, ${ }^{105}$ to acting upon them in a meaningful way.

Adopting an ethics of care approach, in retaining a centrally anthropocentric bent, makes the case for viewing our ecological position realistically and provides the necessary impetus and perspective to urge us towards a more effective approach to climate change than hitherto. It has much to offer in assimilating the importance of relationship, the implications of human vulnerability and our interconnections with one another and the environment, seeing them as motivational, prompting us to take responsibility for our actions through exercising agency and expressing this through the milieu of care vis-à-vis one another and the natural world. However, the ethics of care will not reach its full paradigm-shifting potential if, as is all too often the case with feminist perspectives, it is, "niched' into women's issues." 106 If it is seen for what it is, a different way of approaching difficult issues, an ethics of care approach offers emancipation from destructive ways of thinking and being, and the opportunity to re-vision inter-human and human /nature relationships in ways that offer the promise to sustain both humanity and the environment.

\footnotetext{
${ }^{104}$ Now amply evidenced in the compelling corpus of work by the Intergovernmental Panel on Climate Change, online at $<$ https://www.ipcc-wg3.ac.uk/publicationsanddocuments.html $>$ [accessed on December 13th, 1017].

${ }^{105}$ As is only too evident in the progress of the UNFCCC thus far. See also Atapattu, above n.6.

${ }^{106}$ See Mary Beard, Women and Power: A Manifesto (Profile Books and London Review of Books, 2017$) 25$.
} 